\title{
Synthesis and Characterization of Hydroxyapatite from Duck Eggshell by Wet Precipitation Process
}

\author{
Yelmida Azis* (D), Cory Dian Alfarisi, Komalasari (iD) , Khairat (D) , Yusnimar Sahan \\ Chemical Engineering Department, Universitas Riau, Indonesia
}

\begin{abstract}
Hydroxyapatite ( $\left.\mathrm{HAp}, \mathrm{Ca}_{10}\left(\mathrm{PO}_{4}\right)_{6}(\mathrm{OH})_{2}\right)$ is the most stable form of calcium phosphate and widely used in various medical applications, mainly in orthopedics and dentistry due to its close similarities with the inorganic mineral component of bone and teeth. This study aims to synthesize hydroxyapatite from duck eggshell using the precipitation method. The duck eggshell was calcined, hydrated (slaking) and underwent carbonation to form Precipitated Calcium Carbonate (PCC). Afterwards, $\left(\mathrm{NH}_{4}\right)_{2} \mathrm{HPO}_{4}$ was added to produce HAp by varying the molar ratio of $\mathrm{Ca} / \mathrm{P}$ by $1.67,1.77$ and 1.87 and stirring speed by 200, 250, 300rpm under basic condition ( $\mathrm{pH} 10-11)$. The best results were obtained at a molar ratio of 1.77 with 200rpm stirring speed. Furthermore, the X-ray Diffraction (XRD) analysis showed that its crystals were hexagonal with sizes of $23.062 \mathrm{~nm}$, in the absence of other crystalline phases. Therefore, the hydroxyapatite was obtained in the agglomerates form with a specific surface area of $55.929 \mathrm{~m}^{2} / \mathrm{g}$.
\end{abstract}

Key words: Agglomerates, calcium phosphate, duck eggshell, hydroxyapatite, precipitation.

\section{INTRODUCTION}

Hydroxyapatite, $\mathrm{Ca}_{10}\left(\mathrm{PO}_{4}\right)_{6}(\mathrm{OH})_{2}$, is the main inorganic compound present in hard tissues such as human bone. Consequently, it is readily considered as a bioactive material for artificial bone and teeth substitution because of its biocompatibility, osteoconductivity, chemical and biological affinity with human bone tissues and teeth. Furthermore, it is widely used in biomedical application as filler, coating on bone and dental implants.

Hydroxyapatite is derived from natural resources rich in calcium carbonate $\left(\mathrm{CaCO}_{3}\right)$ like limestone [1], cockle shells [2], egg shells $[3,4]$, animal bone [5] or coral $[6,7]$. In this study, it was synthesized from duck egg shells using precipitation method. The selection of duck egg shells as a source of calcium was due to its abundance in Indonesia. Buasri et al (2013) reported that the content of calcium in the form of calcium oxide $(\mathrm{CaO})$ in duck egg shells was $98,925 \%$.

There are quite number of methods that can be used to produce synthetic nanoparticle HAp such as : precipitation $[8,9]$, hydrothermal $[2,6]$, mechanochemical [10] and sol-gel $[3,11]$. The precipitation method was chosen in this study due to its simple and low-cost processing technique in industrial scale. This method generally produces particles in the nano-scale region and less than $100 \mathrm{~nm}[12]$. However, the hydroxyapatite obtained using this method contains considerable contaminant. Therefore, to solve this problem, HAp was synthesized from duck egg shells through the formation of Precipitated Calcium Carbonate (PCC) using modified carbonation method.

In our previous research, hydroxyapatite was synthesized from cockle shells and eggshells PCC's using hydrothermal and sol gel methods [2,3]. PCC is a calcium carbonate compound $\left(\mathrm{CaCO}_{3}\right)$, which is processed from natural resources containing calcium carbonate through a series of chemical reactions. Its particles are homogenous i.e. same size with micro-scale particles and have high purity (99.8\%). Azis et al, [2] obtained a highly purified hydroxyapatite from PCC cockle shells without any other crystalline phase by using hydrothermal method. Meanwhile, synthesis of hydroxyapatite from PCC duck egg shells using precipitation method has never been previously reported.

\section{MATERIALS AND METHODS}

\subsection{Materials Preperation}

The duck egg shells Fig. 1 were collected from Pekanbaru, Indonesia. Other materials used include diammonium hydrogen phosphate $\left(\left(\mathrm{NH}_{4}\right)_{2} \mathrm{HPO}_{4}\right)$, (Merck), 2M nitric acid (HNO3), 65\% ammonium hydroxide $\left(\mathrm{NH}_{4} \mathrm{OH}\right)$ (Merck), $\mathrm{CO}_{2}$ and aquadest. The duck egg shell samples were thoroughly washed, cleaned and air-dried for two days. Afterwards, they were crushed and grounded to fine powder consistency using a blender.

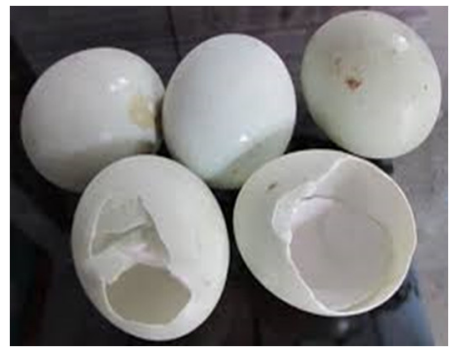

Fig. 1. Duck Egg Shells

$\begin{array}{ll}\text { Received } & \text { : March 26, 2021 } \\ \text { Revised } & \text { : June 14, 2021 } \\ \text { Accepted } & \text { : July 02, 2021 }\end{array}$


2.2. Process of forming precipitated calcium carbonate (PCC) from duck egg shells

The procedure for the formation of PCC from duck egg shells was carried out using the modified carbonation method, referred from Azis et al. [2]. PCC is the main material used in synthesizing hydroxyapatite via precipitation method. The reaction for the formation of PCC using modified carbonation method is represented by the following equations [13].

Calcination :

$2 \mathrm{CaCO}_{3}+$ Heat $\rightarrow 2 \mathrm{CaO}+2 \mathrm{CO}_{2}$

Hydration:

$\mathrm{CaO}+2 \mathrm{HNO}_{3} \rightarrow 2 \mathrm{Ca}\left(\mathrm{NO}_{3}\right)_{2}+\mathrm{H}_{2} \mathrm{O}$

$\mathrm{Ca}\left(\mathrm{NO}_{3}\right)_{2}+2 \mathrm{NH}_{4} \mathrm{O}_{3} \rightarrow \mathrm{Ca}(\mathrm{OH})_{2}+2 \mathrm{NH}_{4} \mathrm{NO}_{3}$

Precipitation :

$\mathrm{Ca}(\mathrm{OH})_{2}+\mathrm{CO}_{2} \rightarrow \mathrm{CaCO}_{3}(\mathrm{PCC})+\mathrm{H}_{2} \mathrm{O}$

2.3 Synthesis of hydroxyapatite from PCC duck egg shells using precipitation method

Because the solubility of PCC in water is very low, its usually dissolved in mineral acid. Therefore, in this study 5 gram of PCC powder from duck egg shells were dissolved in $200 \mathrm{ml}$ of $0.3 \mathrm{M} \mathrm{HNO}_{3}$ solution. Furthermore, $360 \mathrm{ml}$ of $\left(\mathrm{NH}_{4}\right)_{2} \mathrm{HPO}_{4}$ solution was prepared by varying the molar ratio of $\mathrm{Ca}$ and $\mathrm{P}$ reactant by $1.67 ; 1.77$ and 1.87 . Afterwards, it was added in drops to the PCC solution at a rate of $6 \mathrm{ml} / \mathrm{min}$ for $24 \mathrm{~h}$ and stirred at $300 \mathrm{rpm}$. The $\mathrm{pH}$ was monitored at $10-11$ using $33 \% \mathrm{NH}_{4} \mathrm{OH}$. The precipitate object was stirred by using magnetic stirrer at 200, 250 and $300 \mathrm{rpm}$ for $24 \mathrm{~h}$ at room temperature $\left(27^{\circ} \mathrm{C}\right)$ and aged for 24h. Subsequently, it was filtered with a filter paper and repeatedly washed with aquadest until the $\mathrm{pH}$ of solution was 7 . Afterwards, the precipitates were dried at $110^{\circ} \mathrm{C}$ for $24 \mathrm{~h}$ and sintered at $500{ }^{\circ} \mathrm{C}$ for $1 \mathrm{~h}$.

The chemical equations for the reaction are shown below:

$\mathrm{CaCO}_{3(\mathrm{~s})}(\mathrm{PCC})+\mathrm{HNO}_{3(\mathrm{aq})} \rightarrow \mathrm{Ca}\left(\mathrm{NO}_{3}\right)_{2(\mathrm{aq})}$

$10 \mathrm{Ca}\left(\mathrm{NO}_{3}\right)_{2} \cdot 4 \mathrm{H}_{2} \mathrm{O}+6\left(\mathrm{NH}_{4}\right)_{2} \mathrm{HPO}_{4}+8 \mathrm{NH}_{4} \mathrm{OH}$

$\rightarrow \mathrm{Ca}_{10}\left(\mathrm{PO}_{4}\right)_{6}(\mathrm{OH})_{2}+20 \mathrm{NH}_{4} \mathrm{NO}_{3}+20 \mathrm{H}_{2} \mathrm{O}$

\subsection{Characterization}

The hydroxyapatite powder was characterized using X-ray diffraction (X'Pert Powder DY 3688) with $\mathrm{Cu} \mathrm{Ka}$ radiation. Meanwhile, the Fourier Transform Infrared Spectroscopy (FTIR, Perkin Elmer Spectrometer Frontier) was used to analyze the bonding structure of the samples. The surface morphology was probed using scanning electron microscopy (SEM) linked to energy dispersive X-ray microanalysis (EDX) (JEOL JED 2300). Furthermore, the surface area of the hydroxyapatite was characterized using Brunauer-Emmett-Teller (BET) measurements and Surface Area Analyzer (SAA, Quantachrome NovaWin2).

\section{RESULTS AND DISCUSSION}

The FTIR spectrum of HAp powder (Fig. 2 a,b,c) showed the sharpen bands of $\mathrm{PO}_{4}^{-3}$ at $1025-1029 \mathrm{~cm}^{-1}$. According to Stanciu et al. [14], the sharpen peaks of $\mathrm{PO}_{4}^{-3}$ implies that the crystallinity of the hydroxyapatite powder is good. Unfortunately, from Fig. 2 (a) and (b), it is seen that the broad bands at 3370 and $3379 \mathrm{~cm}^{-1}$ were ascribed to the $\mathrm{N}-\mathrm{H}$ asymmetric stretching mode [15]. However, it was assumed that $\mathrm{O}-\mathrm{H}$ stretching mode corresponded to $\mathrm{H}_{2} \mathrm{O}$ at bands $3800-2500 \mathrm{~cm}^{-1}$.

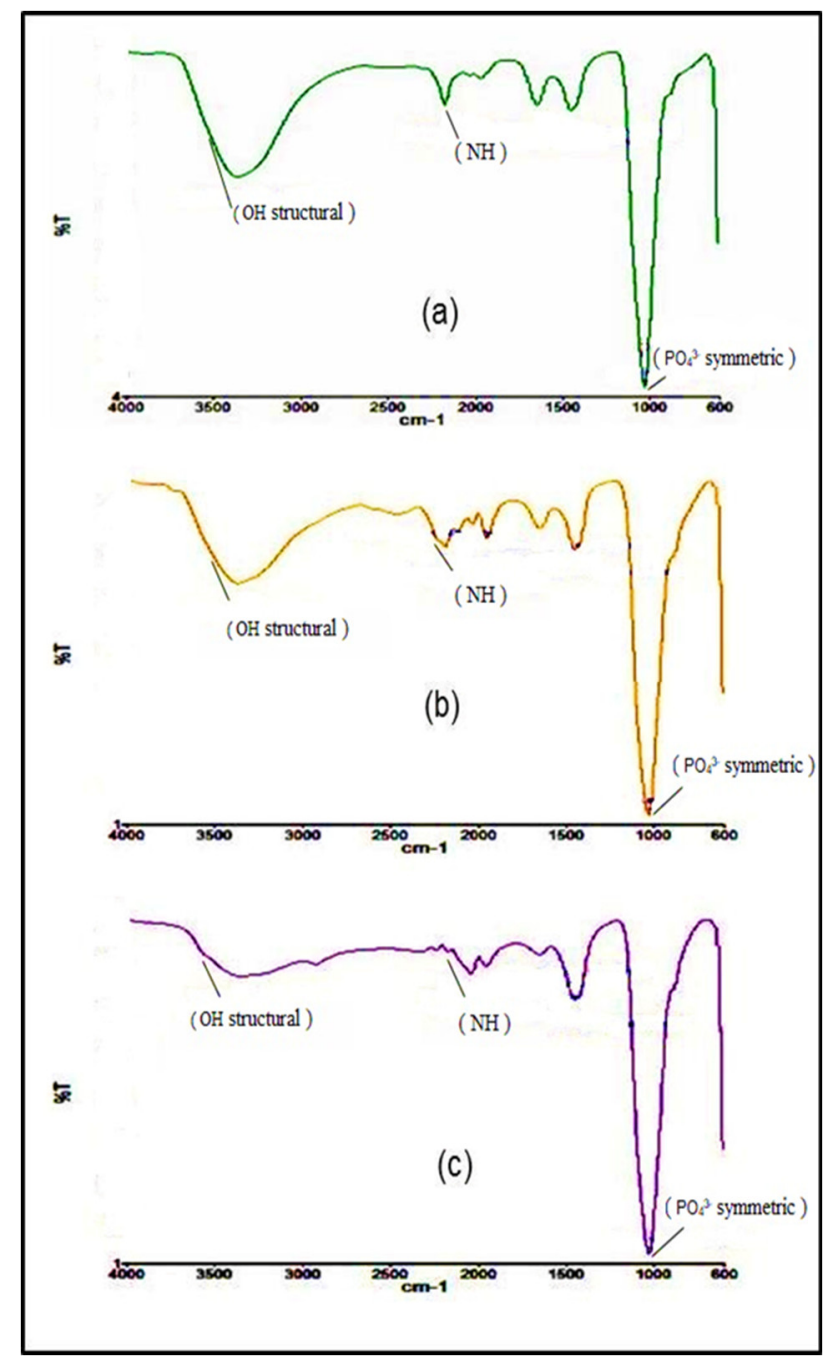

Fig. 2. FTIR spectra of the HAp powder at ratio of $\mathrm{Ca} / \mathrm{P}$ reactant 1.67 and stirring speed (a) 200, (b) 250, (c) 300 rpm

The variation of stirring speed in HAp synthesis did not have a significant influence on the XRD pattern of hydroxyapatite powder (Fig. 3). The XRD pattern of synthesized hydroxyapatite powder was compared to the standard hydroxyapatite ICDD 01-074-4172 (Fig. 3d). The intensity peak was observed at an angle of $2 \theta: 25.8^{\circ}, 28.9^{\circ}$ $31.9^{0}, 32.2^{\circ}, 32.9^{\circ}, 33.9^{\circ}$ and $39.7^{\circ}$, which was very close to the standard ICDD 01-074-4172. Furthermore, the XRD pattern of the synthesized hydroxyapatite powder (Fig. 3a, b, c) did not contain any other crystalline phase.

The morphology and content of element present in the synthesized hydroxyapatite at molar ratio of $\mathrm{Ca}$ and $\mathrm{P}$ reactant : $1.67 ; 1.77$ and 1.87 and stirring speed of $200 \mathrm{rpm}$, were confirmed from the SEM micrograph data as shown in Fig. 4. 


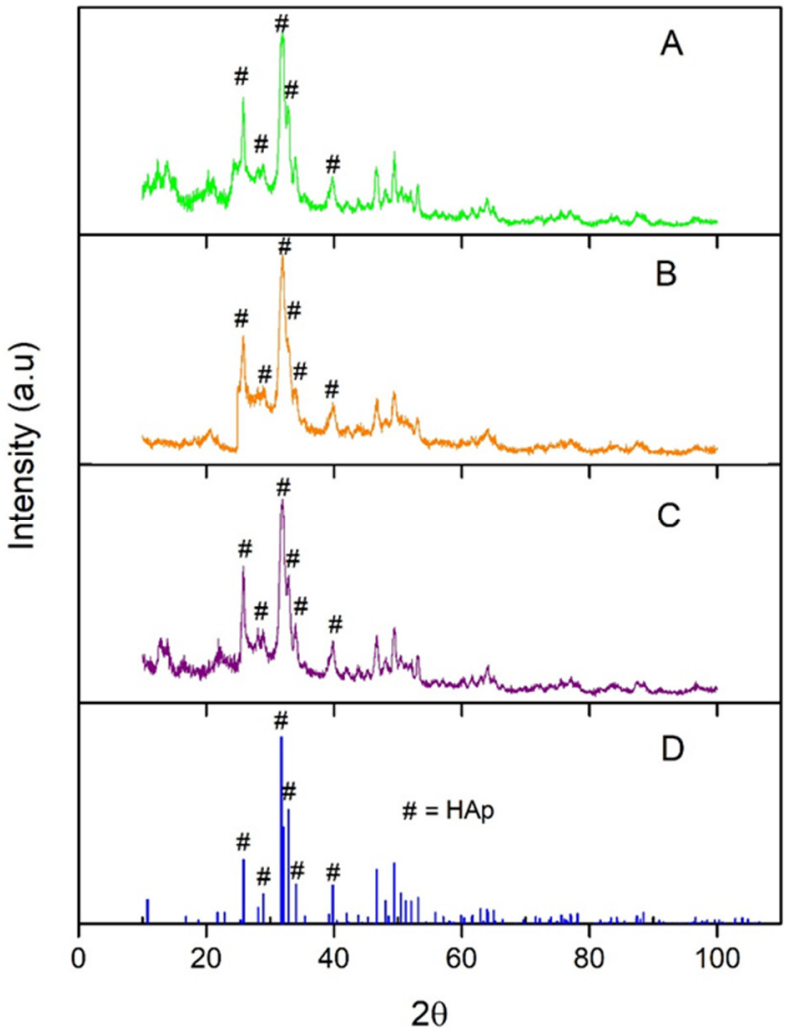

Fig. 3. XRD pattern of HAp powder at stirring speed a)300, b) 250, c) $200 \mathrm{rpm}$, d) HAp standard ICDD 01-074-4172
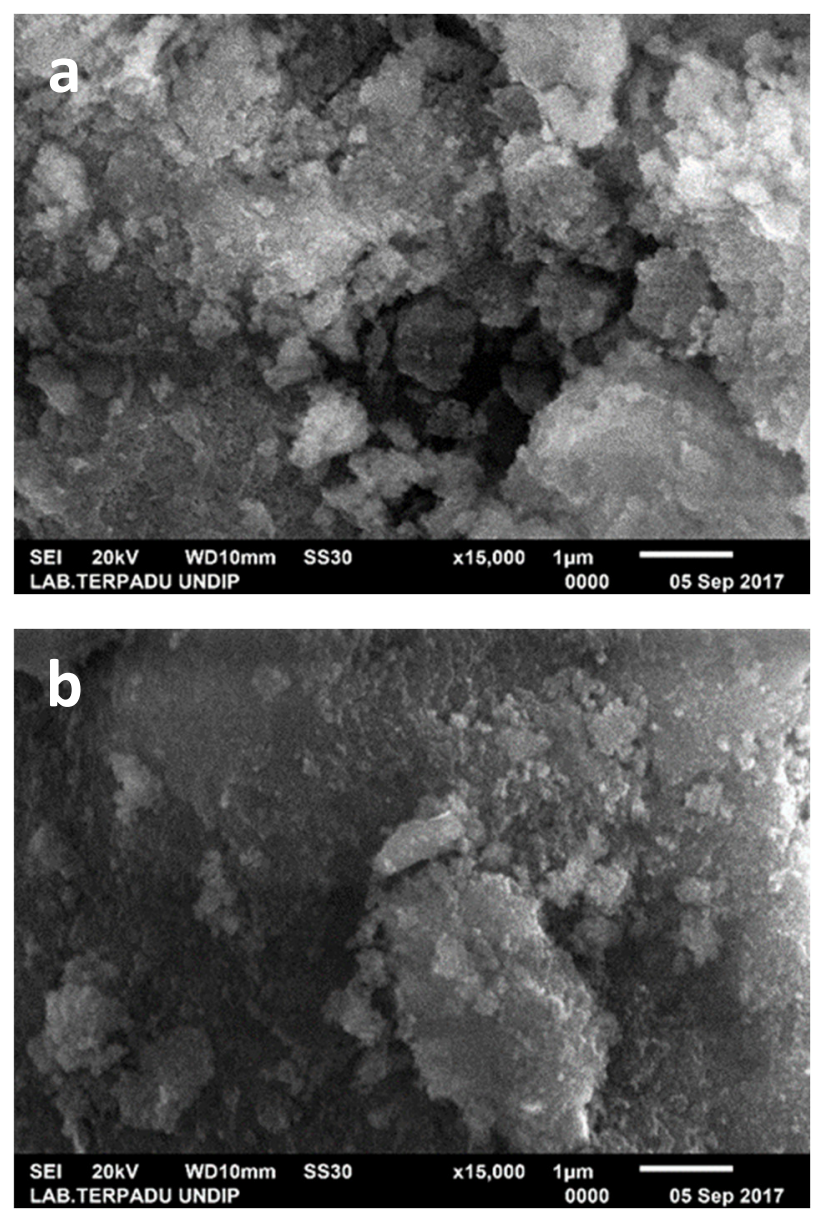

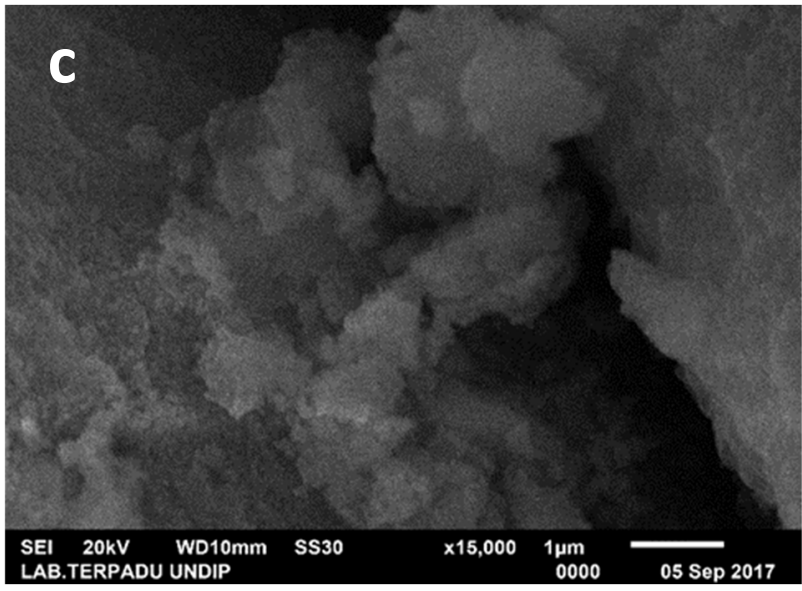

Fig. 4. SEM micrograph of hydroxyapatite powder at 200 rpm and the molar ratio of Ca and P reactant: a) $1.67 \mathrm{~b}) 1.77$ and c) 1.87 .

The diameter of hydroxyapatite crystal was calculated using the Scherrer's equation. The value obtained at the variation of $\mathrm{Ca}$ and $\mathrm{P}$ molar ratio for $200 \mathrm{rpm}$ stirring speed, is shown at Table 1 .

Table 1 The diameter of hydroxyapatite crystal for $200 \mathrm{rpm}$ stirring speed

\begin{tabular}{ccc}
\hline & \multicolumn{2}{c}{ Variable } \\
\cline { 2 - 3 } No & $\begin{array}{c}\mathrm{Ca} / \mathrm{P} \\
\text { reactant }\end{array}$ & $\begin{array}{c}\text { Diameter of HAp } \\
\text { crystal }(\mathrm{nm})\end{array}$ \\
\hline 1 & 1.67 & 23.086 \\
2 & 1.77 & 23.062 \\
3 & 1.87 & 40.356 \\
\hline
\end{tabular}

The best result of the synthesized hydroxyapatite at stirring speed 200rpm and molar ratio of $\mathrm{Ca}$ and $\mathrm{P}$ reactant 1.77 , has crystalline size about $23.062 \mathrm{~nm}$. The measurement of elemental composition ( $\mathrm{Ca}, \mathrm{P}$ and microelement) are summarized in Table 2.

Table $2 \mathrm{Ca}, \mathrm{P}$ and microelement content and $\mathrm{Ca}$ and $\mathrm{P}$ ratio in HAp product

\begin{tabular}{ccc}
\hline Element & $\begin{array}{c}\text { Measured } \\
\text { content }(\text { wt \%) }\end{array}$ & $\begin{array}{c}\text { Ca and P ratio HAp } \\
\text { product }\end{array}$ \\
\hline $\mathrm{P}$ & 17.55 & 1.699 \\
$\mathrm{Ca}$ & 29.83 & \\
$\mathrm{Al}$ & 0.83 & \\
\hline
\end{tabular}

The ratio molar of $\mathrm{Ca}$ and $\mathrm{P}$ hydroxyapatite was synthesized from PCC of duck egg shells was 1.699. The surface area of hydroxyapatite powder was characterized using BET analysis and the value obtained was $55.929 \mathrm{~m} 2 / \mathrm{g}$.

\section{CONCLUSION}

In this study, hydroxyapatite nanoparticle powder was successfully synthesized from the PCC of duck egg shells using precipitation method. The variation of stirring speed did not have a significant influence on the synthesized 
hydroxyapatite. The best hydroxyapatite powder was synthesized at stirring speed 200rpm and molar ratio of $\mathrm{Ca} / \mathrm{P} 1.77$. The XRD pattern showed the high purity of hydroxyapatite and the nano hydroxyapatite crystalline size obtained was $23.062 \mathrm{~nm}$.

\section{AUTHOR INFORMATION}

\section{Corresponding Author}

*Email: yelmida.azis@lecturer.unri.ac.id

\section{ORCID}

Yelmida Azis

: 0000-0003-3141-6415

Komalasari

: 0000-0002-4953-2564

Khairat : 0000-0002-9437-0592

\section{ACKNOWLEDGMENTS}

The authors would like to acknowledge the Kemenristekdikti and Universitas Riau for their financial support under Dana Penelitian Berbasis Kompetensi DRPM and Dana DIPA UNRI

\section{REFERENCES}

[1] Novesar Jamarun, Sirly Yuwan, Ratna Juita, Jumriana Rahayuningsih. Synthesis And Characterization Carbonate Apatite From Bukit Tui Limestone, Padang, Indonesia. Journal of Applicable Chemistry. 2015; 4(2)

[2] Azis Yelmida, Jamarun Novesar, Arief Syukri, Nur Hadi. Facile Synthesis of Hydroxyapatite Particles from Cockle Shells (Anadaragranosa) by Hydrothermal Method. Oriental Journal of Chemistry. 2015; 31(2)

[3] Azis Y, Adrian M, Alfarisi C D, Khairat, Sri R M. Synthesis of hydroxyapatite nanoparticles from egg shells by sol-gel method. IOP Conference Series: Materials Science and Engineering. 2018; 345

[4] Gergely Gréta, Wéber Ferenc, Lukács István, Tóth Attila L., Horváth Zsolt E., Mihály Judit, Balázsi Csaba. Preparation and characterization of hydroxyapatite from eggshell. Ceramics International. 2010; 36(2)

[5] Sri Asliza M. A, Zaheruddin K, Shahrizal H. Study the properties of dense hydroxyapatite-extract from cow bone. Journal of Nuclear and Related Technologies. 2009; 6(1)

[6] Vu Duy Hien, Dao Quoc Huong, Phan Thi Ngoc Bich. Study of the formation of porous hydroxyapatite ceramics from corals via hydrothermal process. Vietnam Journal of Chemistry. 2010; 48(5)

[7] Chou J , Ben-Nissan B , Choi AH , Wuhrer R, Green D. Conversion of coral sand to calcium phosphate for biomedical applications. Journal of the Australian Ceramic Society. 2007; 43(1)

[8] Sriprapha P., S, Eitssayeam U. Intatha, Tunkasiri T. , Rujinagul G., Pengpat K.. Preparation of Hydroxyapatite Nanoparticles with Various Shapes. Journal of the Microscopy Society of Thailand. 2011; 4(2)

[9] Adak M. D, Purohit K. M. Synthesis of Nano- crystalline Hydroxyapatite from Dead Snail Shells for Biological Implantation. Trends in Biomaterials \& Artificial Organs. 2011; 25(3)

[10] Yeong K.C.B., Wang J., Ng S.C.. Mechanochemical synthesis of nanocrystalline hydroxyapatite from $\mathrm{CaO}$ and CaHPO4. Biomaterials. 2001; 22(20)

[11] Sari Tika, Jamarun Novesar, Syukri Syukri, Azharman Zefri, Asril Asregi. Effect of Mixing Temperature on the Synthesis of Hydroxy apatite by Sol-Gel Method. Oriental Journal of Chemistry. 2014; 30(4)

[12] Santos Maria Helena, Oliveira Marise de, Souza Luciana Palhares de Freitas, Mansur Herman Sander, Vasconcelos Wander Luiz. Synthesis control and characterization of hydroxyapatite prepared by wet precipitation process. Materials Research. 2004; 7(4)

[13] Kontrec Jasminka, Ukrainczyk Marko, Babić-Ivančić Vesna, Kralj Damir. Synthesis of Calcium Carbonate by Semicontinuous Carbonation Method in the Presence of Dextrans. Croatica Chemica Acta. 2011.

[14] Stanciu G. A. , Sandulescu I. , Savu B. , Stanciu S. G. , Paraskevopoulos K. M. , Chatzistavrou X. , Kontonasaki E., Koidis P. . Investigation of the Hydroxyapatite Growth on Bioactive Glass Surface. Journal of Biomedical \& Pharmaceutical Engineering. 2007; 1(1)

[15] Barbara H. Stuart. Infrared Spectroscopy: Fundamentals and Applications. John Wiley \&amp; Sons, Ltd; 2004.

This article is licensed under a Creative Commons Attriution 4.0 International License. 